\title{
Tritordeum: Creating a New Crop Species-The Successful Use of Plant Genetic Resources
}

\author{
Carmen M. Ávila ${ }^{1}$, Cristina Rodríguez-Suárez ${ }^{2}$ a and Sergio G. Atienza ${ }^{2, *}$ (]) \\ 1 Área Genómica y Biotecnología, IFAPA—Centro Alameda del Obispo, Apdo 3092, 14080 Córdoba, Spain; \\ carmenm.avila@juntadeandalucia.es \\ 2 Instituto de Agricultura Sostenible (CSIC), Alameda del Obispo, s/n, E-14004 Córdoba, Spain; \\ crodriguez@ias.csic.es \\ * Correspondence: sgatienza@ias.csic.es
}

Citation: Ávila, C.M.;

Rodríguez-Suárez, C.; Atienza, S.G.

Tritordeum: Creating a New Crop

Species-The Successful Use of Plant Genetic Resources. Plants 2021, 10,

1029. https://doi.org/10.3390/

plants10051029

Academic Editor: Rosalyn

B. Angeles-Shim

Received: 30 April 2021

Accepted: 18 May 2021

Published: 20 May 2021

Publisher's Note: MDPI stays neutral with regard to jurisdictional claims in published maps and institutional affiliations.

Copyright: (c) 2021 by the authors. Licensee MDPI, Basel, Switzerland. This article is an open access article distributed under the terms and conditions of the Creative Commons Attribution (CC BY) license (https:// creativecommons.org/licenses/by/ $4.0 /)$

\begin{abstract}
Hexaploid tritordeum is the amphiploid derived from the cross between the wild barley Hordeum chilense and durum wheat. This paper reviews the main advances and achievements in the last two decades that led to the successful development of tritordeum as a new crop. In particular, we summarize the progress in breeding for agronomic performance, including the potential of tritordeum as a genetic bridge for wheat breeding; the impact of molecular markers in genetic studies and breeding; and the progress in quality and development of innovative food products. The success of tritordeum as a crop shows the importance of the effective utilization of plant genetic resources for the development of new innovative products for agriculture and industry. Considering that wild plant genetic resources have made possible the development of this new crop, the huge potential of more accessible resources, such as landraces conserved in gene banks, goes beyond being sources of resistance to biotic and abiotic stresses. In addition, the positive result of tritordeum also shows the importance of adequate commercialization strategies and demonstrative experiences aimed to integrate the whole food chain, from producers to end-point sellers, in order to develop new products for consumers.
\end{abstract}

Keywords: tritordeum; Hordeum chilense; pre-breeding; genetic resources

\section{Introduction}

Rice, maize and common wheat are the most important crops for human consumption in the world. Both rice and maize are diploids, but bread wheat is an allohexaploid $(2 \mathrm{n}=6 \mathrm{x}=42$, AABBDD) derived from the cross between Triticum turgidum (AABB) and Aegilops tauschii (DD) [1]. The allohexaploid genome structure of bread wheat is, in part, responsible for the adaptability of this crop to a wide range of climatic conditions [1].

The wide adaptability of polyploids is an interesting feature for breeding, but alloploidy has not been generally exploited by breeders since it is usually associated with sterility. The first triticale was obtained by Rimpau in 1888, after spontaneous chromosome doubling of hybrids from crosses between bread wheat and rye Rimpau, 1891 (as cited in [2]). The development of triticale from the first cultivars released in the $60 \mathrm{~s}$ to our days, exemplifies the possibilities of alloploidy for the development of new crops (reviewed by [2]).

The success of triticale renewed the interest of developing new synthetic amphiploids between barley and wheat. Plant breeders had been interested in crossing both crops since the beginning of the 20th century (reviewed by [3]), but fertile amphiploids were only obtained when the wild barley Hordeum chilense Roem. et Schultz. was used. This new species was named tritordeum ( $\times$ Tritordeum martini A. Pujadas) [4]. Octoploid [5] and hexaploid [6] tritordeums were obtained from the crosses between $H$. chilense (as mother) and common or durum wheat as pollen donors, respectively. Both tritordeums were initially considered for breeding but the hexaploid became the species of choice 
since octoploid tritordeums showed a high chromosome instability. A similar situation happens in triticale. Although different ploidy levels have been developed and studied, only hexaploid triticale ( $\times$ Triticosecale Wittmack, $2 n=6 x=42$ ) has commercial application (reviewed by [2]).

After two decades of breeding, the potential of tritordeum was clear [3,7]. Hexaploid tritordeum was perceived as an interesting new crop with a similar role to bread wheat in the food industry and with potential as a bridge to transfer useful traits from $H$. chilense to wheat. However, tritordeum breeding still faced significant problems to become a new crop. The most important limitations were the persistence of traits from the wild progenitor, the lack of molecular tools for the effective study and utilization of traits of interests inherited from $H$. chilense and the competition in the food industry with bread wheat-derived products. In this review, we summarize the findings and achievements of the last 20 years which have allowed the successful development of hexaploid tritordeum as a new crop.

\section{Progress in Breeding for Agronomic Performance}

Tritordeum showed a promising potential at the beginning of this century but it still faced significant problems including the retention of traits from its wild progenitor. In first place, tritordeums had brittle rachis. This is an important adaptive trait in the wild that allows an efficient seed dispersion but it is a non-deal trait for agriculture. In addition, tritordeum breeding lines also presented tenacious glumes that interfere with threshing. The combination of both traits resulted in high yield losses during harvesting and constituted a barrier for tritordeum cultivation and commercialization. The improvement of both traits was addressed in the breeding program through the research project 'Breeding of tritordeum' (AGL2005-01381) using two different approaches. The first consisted in the utilization of mutagenic substances in seeds of both $H$. chilense and tritordeum looking for tough rachis mutant phenotypes. This approach was unsuccessful (unpublished results) but allowed the identification of imidazolinone resistant tritordeums due to the mutation in the acetohydroxiacid synthase locus (a single Ser-Asn627 substitution) [8]. This mutation would facilitate an efficient weed management as happens with Clearfield ${ }^{\circledR}$ wheat varieties [9]. Furthermore, this mutated locus has been successfully transferred to durum wheat and constitutes and additional source of resistance to imidazolinone herbicides available in this species [10].

The second approach consisted in a crossing program between hexaploid tritordeum and common wheat. The aim of this research was to obtain free threshing lines throughout the development of chromosome substitution lines. Free threshing is determined by the $Q$ locus in chromosome 5A [11,12] and it controls pleiotropically other traits including glume tenacity and rachis fragility. The extensive search in the breeding program allowed the identification of three hexaploid tritordeum lines (HT374, HT376 and HT382) with free threshing ability [13]. Molecular and cytogenetic characterization of these lines showed that both HT374 and HT376 carried a substitution $5 \mathrm{D} /\left(5 \mathrm{H}^{\mathrm{ch}}\right)$, which suggested the role of an homoeologous $Q$ factor located in $5 \mathrm{H}^{\mathrm{ch}}$. The molecular characterization of the $Q$ gene in wheat [12] allowed the study of this transcription factor in tritordeum. The cloning and characterization of the $Q$ gene from $H$. chilense showed that this gene was absent in HT374 while it was present in HT382 [14]. These results suggest that the free-threshing ability of HT374 was derived from the lack of the AP2-like gene from $H$. chilense in $5 \mathrm{H}^{\mathrm{ch}}$ [14]. On the other hand, the characterization of the breeding line HT382 revealed a double substitution $1 \mathrm{D} /\left(1 \mathrm{H}^{\mathrm{ch}}\right), 2 \mathrm{D} /\left(2 \mathrm{H}^{\mathrm{ch}}\right)$. The Tenacious glume $(\mathrm{Tg})$ locus is located in chromosome $2 \mathrm{D}$ [15] and, thus, the substitution of chromosome $2 \mathrm{H}^{\mathrm{ch}}$, eliminating the homoeologue $\mathrm{Tg}$ locus from $H$. chilense, was considered as the cause of the free threshing ability of HT382 [13].

Regarding yield and agronomic performance, tritordeum breeding lines showed similar behaviour to wheat and triticale elite cultivars under low water conditions [16]. However, further efforts to achieve extended grain filling period and earlier anthesis were required [16]. The continuous breeding pressure allowed the selection of lines with good 
threshing ability, without any bread wheat chromosomes and with yield levels similar to wheat in regions with temperate winters (South of Spain). As a result, two tritordeum varieties, 'Aucan' (grant number 35093), and 'Bulel' (grant number 40872), were registered in the Community Plant Variety Office.

Tritordeum, including 'Bulel', seems better adapted to organic farming than durum wheat since it shows an increase in the below ground community of the Bacteroidetes phylum and better grain quality than durum wheat [17]. However, it has a lower grain yield [17]. However, it is important to note that new advanced lines of tritordeum outperform 'Aucan' and 'Bulel' for yield performance [18]. Table 1 summarizes the agronomic performance data available for tritordeum over time.

Table 1. Agronomic performance of tritordeum lines over time.

\begin{tabular}{|c|c|c|c|c|c|c|}
\hline \multirow[b]{2}{*}{ Plant Material ${ }^{1}$} & \multirow[b]{2}{*}{ Location $^{2}$} & \multicolumn{2}{|c|}{ TKW } & \multicolumn{2}{|c|}{ Yield } & \multirow[b]{2}{*}{ Reference } \\
\hline & & Value (g) & $\begin{array}{c}\text { Relative } \\
\text { Performance }^{3}\end{array}$ & Value (kg/Ha) & $\begin{array}{c}\text { Relative } \\
\text { Performance }\end{array}$ & \\
\hline First HTs & & 36.0 & 66.2 & no data & & [6] \\
\hline Primary tritordeums & Córdoba (Spain) & 35.4 & 65.2 & n.d. & & [2] \\
\hline Breeding lines & Gimenells (Spain) & 33.4 & 64.5 & 2262 & 52.5 & [16] \\
\hline Breeding lines & Tal-Amara (Lebanon) & 27.2 & 64.7 & 2744.5 & 54.6 & [16] \\
\hline Breeding lines & Córdoba (Spain) & 31.5 & 77.6 & 3173.3 & 73.5 & [16] \\
\hline Breeding lines & Granada (Spain) & 33.8 & 85.1 & 2364.5 & 58.9 & [16] \\
\hline Breeding lines & Nabeul (Tunisia) & 22.9 & 66.8 & 1257.5 & 54.7 & [16] \\
\hline Advanced lines & Larisa (Greece) 1st & 29.6 & 103.5 & 4327.5 & 59.0 & [18] \\
\hline JB1 & Larisa (Greece) 1st & 31.4 & 110.0 & 3666 & 50.0 & [18] \\
\hline JB3 & Larisa (Greece) 1st & 28.5 & 99.8 & 3211 & 43.8 & [18] \\
\hline Advanced lines & Larisa (Greece) 2nd & 29.8 & 101.1 & 3480 & 85.8 & [18] \\
\hline JB1 & Larisa (Greece) 2nd & 31.3 & 106.3 & 3189 & 78.6 & [18] \\
\hline JB3 & Larisa (Greece) 2nd & 28.7 & 97.5 & 3196 & 78.8 & [18] \\
\hline Aucan & Écija & n.d. & n.d. & 3404.1 & 117.3 & [19] \\
\hline Aucan & Jerez (Spain) & n.d. & n.d. & 4717.2 & 107.5 & [19] \\
\hline
\end{tabular}

${ }^{1}$ JB1 and JB3 were pre-selections of 'Aucan' and 'Bulel' registered varieties. ${ }^{2}$ Two seasons (denoted as 1 st and 2 nd) were considered by [18].

3 Relative performance compared to bread wheat control with the exception of First HTs that are compared to durum wheat parents.

Tritordeum can also be used as a bridge species to transfer useful traits from $H$. chilense to wheat. H. chilense shows resistance to many diseases which could be exploited for wheat breeding [20]. For instance, tritordeum is resistant to Septoria leaf blotch (STB) due to the gene(s) located on chromosome $4 \mathrm{H}^{\text {ch }}$ of $H$. chilense (reviewed by [20]). The evaluation of resistance to STB on naturally infected trials allows the identification of genes effective against the local isolates, but they may not be effective if diversity at avirulence loci exists [21]. Field trials evaluation in the Czech Republic confirmed the high average resistance of tritordeums for Septoria leaf blotch [22]. The confirmation of the resistance of tritordeum to septoria leaf blotch in a completely different environment from Córdoba (Spain), where the initial resistance tests were conducted, is a good sign showing the potential of the resistance against this pathogen. Substitution lines for $H$. chilense chromosome $4 \mathrm{H}^{\text {ch }}$ into durum wheat have been obtained [23]. Although their performance against STB was not evaluated, they were considered a valuable tool for durum wheat breeding [23]. Similarly, many examples of successful introgression of $H$. chilense into wheat genetic background are available [24-34]. H. chilense-wheat translocation lines have been developed (Table 2). Nevertheless, to our knowledge, the transference of these introgressions into elite wheat material is still pending.

In addition, tritordeum is also considered a potential source to introgress genes for the combined stress of drought and salinity, as well as to each of these stresses separately [35] and for the development of hybrid wheat using a cytoplasm male sterility (msH1 system) $[26,27,36]$. The utilization of $\mathrm{msH} 1$ system for the production of hybrid bread [37] and durum wheat [38] is a clear example of the benefits of tritordeum for the improvement of wheat. 
Table 2. Translocation lines (TL) of H. chilense in bread wheat (BW) and durum wheat (DW).

\begin{tabular}{lcl}
\hline Genetic Stock & Chromosome & Main Traits \\
\hline TL in BW [25] & $2 \mathrm{H}^{\text {ch }}$ & Carotenoid [39] and PPO1 and PPO2 genes [40]; \\
TL in BW [30] & $3 \mathrm{H}^{\mathrm{ch}}$ & $\begin{array}{l}\text { eLcy [39]; carotenoid content [41] } \\
\text { TL in DW [23] }\end{array}$ \\
$4 \mathrm{H}^{\mathrm{ch}}$ & $\begin{array}{l}\text { STB and greenbug resistance [20]; salinity [42] } \\
\text { Mildew and greenbug resistance [20]; }\end{array}$ \\
TL in BW [43] & $5 \mathrm{H}^{\mathrm{ch}}$ & $\begin{array}{l}\text { Hordeoindolines [43]; Salt tolerance [42]; Carotenoid } \\
\text { genes [39] }\end{array}$ \\
TL in BW [27]; TL in DW [38] & $6 \mathrm{H}^{\mathrm{ch}}$ & $\begin{array}{l}\text { Fertility restoration [27,34,37,38] } \\
\text { Carotenoid content [31,44,45]; carotenoid } \\
\text { esterification [45,46]; mildew and greenbug } \\
\text { resistance [20]; waxy protein [47] }\end{array}$ \\
\hline
\end{tabular}

\section{Impact of Molecular Markers in Genetics and Breeding}

The properties of tritordeum are influenced to a great extent by $H$. chilense genome. In this context, the development of genetic studies and the characterization of plant breeding materials, including introgression lines, could benefit from the application of molecular markers. Progress in genomics during the last two decades have made possible the genotyping with thousands of markers with a low cost per data and in a short time. However, the situation was very different two decades ago. No DNA markers were available for $H$. chilense at the early stages of tritordeum breeding [3]. Thus, a considerable effort was employed for the development of molecular markers suitable for genetic studies in $H$. chilense and for the development of marker assisted introgression of $H$. chilense chromatin into wheat background using RAPDs, AFLP, SSR and RFLP (reviewed by [48]. RAPDs and AFLP markers allowed the first mapping studies in H. chilense [49-51]. However, the lack of enough markers for comparative studies among species, such as SSR of RFLP, constituted a serious drawback in order to exploit the knowledge generated in related cereals. Genomic studies in barley allowed the development of EST markers in a much larger scale than previously known. The transferability of these markers to $H$. chilense [51-53] constituted a qualitative jump for the identification of $H$. chilense chromosomes in wheat background. Indeed, these markers have been successfully used for the identification of $H$. chilense chromosomes in tritordeum [13] and for the identification of $H$. chilense chromosomes during the development of wheat- $H$. chilense genetic stocks for chromosomes $1 \mathrm{H}^{\text {ch }}$ [24]; $2 \mathrm{H}^{\text {ch }}[25] ; 3 \mathrm{H}^{\text {ch }}[30] ; 4 \mathrm{H}^{\text {ch }}[23,32], 6 \mathrm{H}^{\text {ch }}[27]$ and $7 \mathrm{H}^{\text {ch }}[28,29]$.

The synthesis of new allopolyploids results in the elimination of chromosome- and genome-specific sequences contributing to the diploid-like meiotic behaviour [54]. Furthermore, this elimination is non-random and directional, and contributes to the diploid-like behaviour of the amphiploids [54]. The existence of these rearrangements was studied in tritordeum with different types of markers including inter-retrotransposon amplified polymorphism (IrAP), retrotransposon-microsatellite amplified polymorphism (REMAP) and Start Codon Targeted (SCOT) polymorphisms $[55,56]$. The elimination of H. chilense sequences, as deduced from the fact that the majority of SCoT markers were derived from wheat instead of from H. chilense, reinforced the potential of tritordeum as a new crop [55].

Despite the progress in the application of molecular markers, advances in sequencing techniques and microarray-based markers constituted another qualitative change for genetic studies in $H$. chilense and tritordeum. In particular, DArT markers allowed the development of thousands of markers widely distributed throughout $H$. chilense genome. These markers were used for the construction of a genetic map with a good coverage [57] and for the genetic characterization of tritordeum breeding lines [58]. Furthermore, this new genetic map was completed with barley ESTs [59] and COS markers [60], providing the bases for preliminary macro-synteny studies of $H$. chilense with other Triticeae species. The genomic coverage obtained with this genetic map made possible the location of candidate genes including carotenoid and polyphenol oxidase genes [39,40] and the mapping of the fertility restoration locus in chromosome $6 \mathrm{H}^{\text {ch }}$ [33] in the wheat-msH1 cytoplasmic male sterility system useful for hybrid wheat production [27]. The correspondence of 
the location of all these genes in H. chilense with their homoeologues in other Triticeae species, suggested a good degree of collinearity between $H$. chilense and the rest of the tribe members. After this, the development of DArTSeq markers in $H$. chilense, along with the availability of the barley genome sequence in public repositories [61], made it possible to study the synteny relations between $H$. chilense and barley in detail [62]. In general, $H$. chilense shows a good degree of collinearity with barley with the exception of a major rearrangement in chromosome $7 \mathrm{H}^{\mathrm{ch}}$, where $H$. chilense carries a reciprocal translocation between the distal part of this chromosome [62]. The break of synteny at $7 \mathrm{H}^{\text {ch }}$ was suspected since the main locus for endosperm carotenoid content in $H$. chilense has been located in chromosome $7 \mathrm{H}^{\text {ch }} \mathrm{S}$ [44], while the orthologous was located in chromosome 7BL in durum wheat [63]. DArTSeq markers have been used for Genome-Wide Association Scan studies in H. chilense [62] and they have also contributed to the study of the cytoplasmic male sterility msH1 system [27] for the production of hybrid wheat. In particular, DArTSeq markers allowed the characterization of an acrocentric chromosome carrying the restorer-of-fertility gene [33] as a previous step for the identification of the candidate gene [37].

\section{Progress in Quality and Potential for the Development of New Innovative Food Products}

Although durum wheat is the male parent of hexaploid tritordeum, the grain texture of tritordeum is similar to that of bread wheat [64]. This quality parameter is controlled in wheat by the puroindoline genes (Pina-D1 and Pinb-D1) located on chromosome 5D [65] and the homoeologue hordoindoline genes Hina and Hinb in barley. Hina-Hch1 and HinbHch1 genes in H. chilense are very similar to Pin genes of bread wheat [66], which may explain the soft grain texture of tritordeum. Indeed, the addition of chromosome $5 \mathrm{H}^{\text {ch }}$ to bread wheat resulted in the enhancement of grain softness [67]. This makes tritordeum flour more adequate for the production of products similar to those obtained from bread wheat. Accordingly, High Molecular Weight (HMW) glutenin subunits were considered a primary target for tritordeum breeding due to their high influence on breadmaking quality [68]. Two alternative approaches were applied: transgenic and conventional breeding. The transgenic alternative allowed the development of tritordeum lines expressing HMW genes $1 \mathrm{Ax} 1$ and $1 \mathrm{Dx} 5[69,70]$. On the other hand, chromosome substitution or translocation lines with the HMW glutenin subunits Dx5 + Dy10 were obtained by conventional methods [71]. The chromosome substitution lines obtained showed a similar agronomic performance than the euploid tritordeum, but they had a much higher gluten strength due to the addition of HMW glutenin subunits 1D [72].

The breadmaking quality of tritordeum is also influenced to a great extent by the $H$. chilense genome (reviewed by [3]). This promoted the study of the variability for endosperm storage proteins in the H. chilense accessions used to develop primary tritordeums [73-75], along with the diversity in the natural populations of the species [76]. Further studies focused on the effect of these proteins in breadmaking quality in tritordeums $[77,78]$. In summary, these studies revealed a wide diversity for storage proteins potentially useful for both tritordeum and wheat breeding, which could provide new functionalities not found in other cereals. Indeed, tritordeum has significantly lower levels of $\omega$-gliadins in flour and levels of gluten around 50\% lower than wheat [79]. Accordingly, tritordeum is considered an interesting choice to people wishing to reduce their gluten intake, although it is not suitable for patients suffering coeliac disease [79]. Furthermore, tritordeum bread has been recommended for a subset of non-celiac wheat sensitivity patients who do not need strict exclusion of gluten from their diet [80].

The increasing demand of healthier foods, including whole grain-derived foods, has promoted the investigation of other health related traits in tritordeum. Phenolic compounds are the main group of phytochemicals in barley grain and their main interest is due to their strong antioxidant power and their association to certain diseases prevention [81]. Considering that tritordeum expresses the properties of both barley and wheat, its phenolic content and profile was investigated [82]. A great variability for phenolic compounds content was reported, ferulic acid being the main one that happens in wheat [82]. However, 
comparative studies with wheat and barley showed that advanced lines of tritordeum have a similar total phenolic content to wheat but much lower than barley [83]. Phenolic content has not been a target in tritordeum breeding program and, thus, it might be possible that valuable diversity for this trait remains hidden in pre-breeding materials or in $H$. chilense accessions. However, total phenolic content in tritordeum was around half the reported in barley [83] and, thus, it is not likely that tritordeum could outperform barley as a natural source for these compounds.

Accumulation of compounds such as tocols [84] or polysaccharides (arabinoxylans and $\beta$-glucans) [85] has been also studied in tritordeum, along with the potential for accumulation of micronutrients as Selenium in grain [86]. Furthermore, the essential role of Selenium in animal and human nutrition promoted the evaluation of selenium fertilized tritordeum in relation to conventional dietary supplements of this micronutrient in laying hens [87]. The improvement of egg quality due to Se-enriched tritordeum suggests that selenium-fertilized tritordeum may be an interesting alternative for animal feeding [87].

Tritordeum can be also used for cake [88] and beer production [89]. Indeed, tritordeum and barley malts yielded comparable values for the majority of technological parameters including alcohol content, although tritordeum malts produced a slight acidification effect, a lower level of glucose and a higher amount of free amino nitrogen [89]. Besides, tritordeum malt did not cause any technological problem during the different stages of beer production and, thus, it is considered that it has a high potential for the brewing industry [89]. Furthermore, the utilization of brewers' spent grain from tritordeum, the major by-product of the brewing industry, may increase the nutritional potential of durum wheat pasta [90], by improving total antioxidant capacity, total dietary fibre and $\beta$-glucans and without compromising the sensory aspects of pasta [90]. All these findings show the potential of tritordeum for the development of food products with new functionalities.

Regarding health-related compounds, carotenoid content has been the most extensively studied due to its importance on the appearance of tritordeum products. The intensive yellow colour of tritordeum flour constitutes an important differential characteristic compared to bread wheat derived products [3]. This trait could be perceived as detrimental since white flour is usually preferred for breadmaking from bread wheat. As a consequence, initial studies confirmed the lack of effect of yellow colour in relation with the baking performance [3]. The high carotenoid content in the endosperm is responsible for the golden coloration of tritordeum products and it confers a clear differentiation from standard bread wheat products. Instead of a detrimental trait, the high carotenoid content was considered a potential commercial advantage. This motivated the study of the genetic bases of carotenoid content, which resulted in the identification of a QTL in chromosome $2 \mathrm{H}^{\text {ch }}$ [50], the selection of new genotypes with high carotenoid content such as HT621 [91] and the development of selection tools useful for the breeding program [92]. The genes responsible for carotenoid content in tritordeum and wheat were unknown at the time although they have been located in chromosomes $7 \mathrm{H}^{\mathrm{ch}}$ [44] and 7B [63]. Thus, a candidate gene approach using rice as a model species and the gene Phytoene synthase 1 was performed. Our results proved that Psy1 was located in chromosome $7 \mathrm{H}^{\text {ch }} \mathrm{S}$ in $H$. chilense and 7A and 7B in durum wheat [93]. Furthermore, the diagnostic marker developed for Psy1_Hch [93] was successfully used for marker assisted selection of Psy1_Hch in bread wheat- $H$. chilense genetic stocks $[28,45]$. The cloning and heterologous expression in bacteria of Psy1_Hch confirmed the functionality of this gene [94] and its potential for the enhancement of carotenoids in wheat.

Further transcriptomic experiments showed that both Psy1 and e-Lcy (Lycopene epsilon cyclase) were upregulated between 18 and 25 days after anthesis in tritordeum, while their homoeologue genes in durum wheat were downregulated [41]. The differences in the expression profile between tritordeum and durum wheat were associated with the differences in carotenoid content between both species [41]. The development of translocation lines of $H$. chilense $7 \mathrm{H}^{\text {ch }}$ S into bread wheat resulted, as expected, in the increase in endosperm carotenoid content due to the presence of Psy1_Hch [31]. 
In addition, tritordeums have a high proportion of carotenoid esters in contrast with durum wheat [95]. Esterification is a common way to accumulate carotenoids in plants [96]. Thus, it was hypothesized that the activation of the carotenoid pathway in tritordeum during grain development may be associated with the synthesis of carotenoid esters and the production of a metabolic sink. However, this hypothesis was not confirmed since no lutein esters are produced before 36 days after anthesis [97]. Nevertheless, carotenoid esterification can contribute to the accumulation of lutein in tritordeum endosperm by limiting carotenoid degradation in later stages [97].

The importance of esterified carotenoids goes beyond their role in carotenoid accumulation since they have a higher stability than free carotenoids [98,99]. Higher carotenoid retention has been observed during post-harvest storage due to esterification [98,100-102] and, thus, the increase in carotenoid esterification is a good target for the improvement of carotenoid retention in the food chain. This is relevant for tritordeum since this species has a high proportion of carotenoids in the esterified form in the endosperm $[95,97,103]$, with a 3-fold higher content in the endosperm compared to the germ [104].

The potential of esterification for the improvement of carotenoid retention through the food chain has increased the interest on this trait despite these results are not confirmed at high-temperature regimes [105]. The identification of the xanthophyll acyl transferase (XAT7D), responsible for carotenoid esterification in common wheat, opens new possibilities for marker assisted selection [106]. In fact, this gene is being transferred from common to durum wheat at present [107]. In tritordeum, carotenoid esterification is due to the $H$. chilense genome [108]. In particular, candidate genes at chromosome $7 \mathrm{H}^{\mathrm{ch}}$ were identified by physical mapping and DArTSeq markers [109]. Recently, a GDSL esterase/lipase (XAT-7Hch), orthologue of XAT-7D, has been identified as the main responsible for lutein esterification in $H$. chilense/tritordeum [46]. As happens with XAT-7D, this gene can be used for wheat breeding through a marker assisted selection strategy with a diagnostic marker already available [46].

Table 3 summarizes the main quality attributes of tritordeum grain.

Table 3. Grain quality parameters in tritordeum.

\begin{tabular}{|c|c|c|c|}
\hline Trait & Value & Relative Performance Over Control ${ }^{1}$ & Reference \\
\hline Carotenoid content $(\mu \mathrm{g} / \mathrm{g})$ (Primary tritordeums) & 5.8 & 4.8-fold increase (DW) & [95] \\
\hline Carotenoid content ( $\mu \mathrm{g} / \mathrm{g})$ (Breeding lines) & 9.14 & 2.8-fold increase (DW) & [41] \\
\hline Carotenoid content (Bread) $(\mu \mathrm{g} / 100 \mathrm{~g})$ & 357.6 & 6.5-fold increase (BW) & [19] \\
\hline Carotenoid esterification (\%) & 33.8 & not detected (DW) & [41] \\
\hline Gluten content & n.a. & $51 \%$ reduction $(\mathrm{BW})$ & {$[79,80]$} \\
\hline$\gamma$-gliadin epitopes & n.a. & $59 \%$ reduction $(\mathrm{BW})$ & {$[79,80]$} \\
\hline$\alpha$-gliadin epitopes & n.a. & $77 \%$ reduction (BW) & {$[79,80]$} \\
\hline Total tocols $(\mu g / g)$ & 30.2 & Similar to BW & {$[84]$} \\
\hline Beta-glucans (\% dry matter) & 0.6 & Similar to BW; $90 \%$ reduction (B) & [85] \\
\hline
\end{tabular}

${ }^{1} \mathrm{DW}=$ durum wheat; BW = Bread wheat; $\mathrm{B}=$ Barley.

The high carotenoid content of tritordeum has been used to widen the interest in this 'Golden Cereal' (https: / / www.tritordeum.com/?lang=en\#whatis, accessed on 20 May 2021). Agrasys S.L., Barcelona, Spain, a spin-off of the Spanish High Council for Scientific Investigations (CSIC), has benefited from the commercial exploitation of tritordeum, as it has held the exclusive commercial rights of tritordeum since 2006. The registration of the tritordeum varieties 'Aucan' and 'Bulel' at the Community Plant Variety Office, along with the commercialization effort developed by Agrasys, has made the expansion of tritordeum possible to many countries (https:/ / www.tritordeum.com/ww/?lang=en, accessed on 20 May 2021); more importantly, it has made tritordeum products available to consumers. At present, there is a complete food chain comprised of farmers, millers, bakers and sellers for the development of tritordeum products. 


\section{Final Remarks}

The success of tritordeum as a crop offers important lessons. In the first place, it shows the importance of the effective utilization of plant genetic resources, including wild species, for the development of innovative products for agriculture and food industry. The utilization of plant genetic resources must be encouraged and promoted, since they hold the key for further success in the current scenario of climate change, and to provide the food industry with new products to meet the consumer's preferences. Considering that the use of wild germplasm, without any adaptation to agriculture, has been used to develop a new crop, plant genetic resources conserved in germplasm banks have huge potential for plant breeding that goes beyond being sources of resistance to pest and diseases. The development of introgressions of $H$. chilense into common and durum wheat genetic backgrounds holds potential for the improvement of wheat. However, the transference of these introgressions into elite wheat material is still pending.

In second place, the development of innovative products is not enough to produce a significant impact in the food industry. In this context, the efforts carried out by Agrasys S.L. have promoted the interest of producers, millers and consumers in tritordeum, through adequate commercialization strategies and demonstrative experiences, which have allowed the consumption of tritordeum in an ever-growing list of countries around the world.

Author Contributions: S.G.A. did the first literature review and wrote the first draft of the manuscript. C.R.-S. and C.M.Á. gave scientific involvement, evaluated critically the review and contributed to the final version of the manuscript. All authors have read and agree to the final version of the manuscript. All authors have read and agreed to the published version of the manuscript.

Funding: This research was funded by Ministerio de Ciencia, Innovación y Universidades, grant number AGL2017-85368-P and cofounded by FEDER.

Institutional Review Board Statement: Not applicable.

Informed Consent Statement: Not applicable.

Data Availability Statement: No data are contained within the article.

Acknowledgments: Dedicated to A. Martín, the father of tritordeum, and to the memory of Juan Ballesteros, the tritordeum breeder. Their dedication, enthusiasm and vision were crucial to the development of tritordeum as a crop.

Conflicts of Interest: The authors declare no conflict of interest. The funders had no role in the design of the study; in the collection, analyses, or interpretation of data; in the writing of the manuscript, or in the decision to publish the results.

\section{References}

1. International Wheat Genome Sequencing Consortium. A chromosome-based draft sequence of the hexaploid bread wheat (Triticum aestivum) genome. Science 2014, 345, 1251788. [CrossRef] [PubMed]

2. Mergoum, M.; Singh, P.K.; Peña, R.J.; Lozano-del Río, A.J.; Cooper, K.V.; Salmon, D.F.; Gómez Macpherson, H. Triticale: A “New” Crop with Old Challenges. In Cereals; Springer: Berlin/Heidelberg, Germany, 2009; pp. 267-287.

3. Martín, A.; Alvarez, J.B.; Martín, L.M.; Barro, F.; Ballesteros, J. The development of tritordeum: A novel cereal for food processing. J. Cereal Sci. 1999, 30, 85-95. [CrossRef]

4. Pujadas, A.J. $\times$ Tritordeum martinii A. pujadas (Poaceae) Nothosp. Nov. Acta Bot. Malacit. 2016, 41, 325-338. [CrossRef]

5. Martin, A.; Chapman, V. A hybrid between Hordeum chilense and Triticum aestivum. Cereal Res. Commun. 1977, 5, 365-368.

6. Martin, A.; Sánchez-Monge, E. Cytology and morphology of the amphiploid Hordeum chilense $\times$ Triticum turgidum conv durum. Euphytica 1982, 31, 261-267. [CrossRef]

7. Martin, A.; Martínez, C.; Rubiales, D.; Ballesteros, J. Tritordeum: Triticale's new brother cereal. In Triticale: Today and Tomorrow; Güedes-Pinto, H., Darvey, N., Carnide, V.P., Eds.; Kluwer Academic Publishers: Dordrecht, The Netherlands, 1996; pp. 57-72.

8. Rodríguez-Suárez, C.; Ramírez, M.C.; Martínez, C.; Nadal, S.; Martín, A.; Atienza, S.G. Selection and molecular characterization of imidazolinone resistant mutation-derived lines of Tritordeum HT621. Mol. Breed. 2009, 23, 565-572. [CrossRef]

9. Ball, D.; Peterson, C. Herbicide Tolerance in Imidazolinone-Resistant Wheat for Weed Management in the Pacific Northwest U.S.A. In Wheat Production in Stressed Environments; Springer: Dordrecht, The Netherlands, 2007; pp. 243-250.

10. Domínguez-Mendez, R.; Alcántara-De La Cruz, R.; Rojano-Delgado, A.M.; Fernández-Moreno, P.T.; Aponte, R.; De Prado, R. Multiple mechanisms are involved in new imazamox-resistant varieties of durum and soft wheat. Sci. Rep. 2017, 7. [CrossRef] 
11. Faris, J.D.; Fellers, J.P.; Brooks, S.A.; Gill, B.S. A bacterial artificial chromosome contig spanning the major domestication locus Q in wheat and identification of a candidate gene. Genetics 2003, 164, 311-321. [CrossRef] [PubMed]

12. Simons, K.J.; Fellers, J.P.; Trick, H.N.; Zhang, Z.; Tai, Y.S.; Gill, B.S.; Faris, J.D. Molecular Characterization of the Major Wheat Domestication Gene Q. Genetics 2006, 172, 547-555. [CrossRef] [PubMed]

13. Atienza, S.G.; Martín, A.C.; Martín, A. Introgression of wheat chromosome 2D or 5D into tritordeum leads to free-threshing habit. Genome 2007, 50, 994-1000. [CrossRef]

14. Gil-Humanes, J.; Piston, F.; Martin, A.; Barro, F. Comparative genomic analysis and expression of the APETALA2-like genes from barley, wheat, and barley-wheat amphiploids. BMC Plant Biol. 2009, 9, 66. [CrossRef]

15. Jantasuriyarat, C.; Vales, M.I.; Watson, C.J.W.; Riera-Lizarazu, O. Identification and mapping of genetic loci affecting the freethreshing habit and spike compactness in wheat (Triticum aestivum L.). Theor. Appl. Genet. 2004, 108, 261-273. [CrossRef] [PubMed]

16. Villegas, D.; Casadesús, J.; Atienza, S.G.; Martos, V.; Maalouf, F.; Karam, F.; Aranjuelo, I.; Nogués, S. Tritordeum, wheat and triticale yield components under multi-local mediterranean drought conditions. Field Crop. Res. 2010, 116, 68-74. [CrossRef]

17. Visioli, G.; Lauro, M.; Vamerali, T.; Dal Cortivo, C.; Panozzo, A.; Folloni, S.; Piazza, C.; Ranieri, R. A comparative study of organic and conventional management on the rhizosphere microbiome, growth and grain quality traits of tritordeum. Agronomy 2020, 10, 1717. [CrossRef]

18. Kakabouki, I.; Beslemes, D.F.; Tigka, E.L.; Folina, A.; Karydogianni, S.; Zisi, C.; Papastylianou, P. Performance of six genotypes of tritordeum compare to bread wheat under east mediterranean condition. Sustainability 2020, 12, 9700. [CrossRef]

19. Barceló, P. Tritordeum, un nuevo cereal natural. In Jornadas Técnicas "Rotaciones y Diversidad en Agricultura"; Agrocon e Ibercide; Fundación Ibercaja: Zaragoza, Spain, 2014.

20. Rubiales, D.; Niks, R.E.; Carver, T.L.W.; Ballesteros, J.; Martín, A. Prospects for Exploitation of Disease Resistance from Hordeum chilense in Cultivated Cereals. Hereditas 2001, 135, 161-169. [CrossRef]

21. Brown, J.K.M.; Chartrain, L.; Lasserre-Zuber, P.; Saintenac, C. Genetics of resistance to Zymoseptoria tritici and applications to wheat breeding. Fungal Genet. Biol. 2015, 79, 33-41. [CrossRef]

22. Martinek, P.; Svobodová, I.; Věchet, L. Selection of the Wheat Genotypes and Related Species with Resistance to Mycosphaerella graminicola. Agriculture 2013, 59, 65-73. [CrossRef]

23. Calderón, M.C.C.; Ramírez, M.C.C.; Martín, A.; Prieto, P. Development of Hordeum chilense 4Hch introgression lines in durum wheat: A tool for breeders and complex trait analysis. Plant Breed. 2012, 131, 733-738. [CrossRef]

24. Cherif-Mouaki, S.; Said, M.; Alvarez, J.B.; Cabrera, A. Sub-arm location of prolamin and EST-SSR loci on chromosome $1 \mathrm{H}^{\mathrm{ch}}$ from Hordeum chilense. Euphytica 2011, 178, 63-69. [CrossRef]

25. Palomino, C.; Cabrera, A. Development of wheat-Hordeum chilense Chromosome $2 \mathrm{H}^{\text {ch }}$ Introgression Lines Potentially Useful for Improving Grain Quality Traits. Agronomy 2019, 9, 493. [CrossRef]

26. Martin, A.C.; Atienza, S.G.; Ramirez, M.C.; Barro, F.; Martin, A. Chromosome engineering in wheat to restore male fertility in the msH1 CMS system. Mol. Breed. 2009, 24, 397-408. [CrossRef]

27. Martín, A.C.; Atienza, S.G.; Ramírez, M.C.; Barro, F.; Martín, A. Male fertility restoration of wheat in Hordeum chilense cytoplasm is associated with $6 \mathrm{H}^{\text {ch }} \mathrm{S}$ chromosome addition. Aust. J. Agric. Res. 2008, 59, 206-213. [CrossRef]

28. Mattera, M.G.; Ávila, C.M.; Atienza, S.G.; Cabrera, A. Cytological and molecular characterization of wheat-Hordeum chilense chromosome 7H $\mathrm{H}^{\text {ch }}$ introgression lines. Euphytica 2015, 203, 165-176. [CrossRef]

29. Mattera, M.G.; Cabrera, A. Characterization of a set of common wheat-Hordeum chilense chromosome 7Hch introgression lines and its potential use in research on grain quality traits. Plant Breed. 2017, 136, 344-350. [CrossRef]

30. Said, M.; Recio, R.; Cabrera, A. Development and characterisation of structural changes in chromosome $3 \mathrm{H}^{\mathrm{ch}}$ from Hordeum chilense in common wheat and their use in physical mapping. Euphytica 2012, 188, 429-440. [CrossRef]

31. Rey, M.-D.; Calderón, M.-C.; Rodrigo, M.J.; Zacarías, L.; Alós, E.; Prieto, P. Novel bread wheat lines enriched in carotenoids carrying Hordeum chilense chromosome arms in the ph1b background. PLoS ONE 2015, 10. [CrossRef]

32. Said, M.; Cabrera, A. A physical map of chromosome $4 \mathrm{H}^{\mathrm{ch}}$ from $H$. chilense containing SSR, STS and EST-SSR molecular markers. Euphytica 2009, 167, 253-259. [CrossRef]

33. Castillo, A.; Atienza, S.G.; Martín, A.C. Fertility of CMS wheat is restored by two Rf loci located on a recombined acrocentric chromosome. J. Exp. Bot. 2014, 65, 6667-6677. [CrossRef]

34. Castillo, A.; Rodríguez-Suárez, C.; Martín, A.C.; Pistón, F. Contribution of chromosomes $1 \mathrm{H}^{\text {ch }} \mathrm{S}$ and $6 \mathrm{H}^{\text {ch }} \mathrm{S}$ to fertility restoration in the wheat msH1 CMS system under different environmental conditions. PLoS ONE 2015, 10. [CrossRef] [PubMed]

35. Yousfi, S.; Serret, M.D.; Voltas, J.; Araus, J.L. Effect of salinity and water stress during the reproductive stage on growth, ion concentrations, delta C-13, and delta N-15 of durum wheat and related amphiploids. J. Exp. Bot. 2010, 61, 3529-3542. [CrossRef]

36. Martín, A.C.C.; Atienza, S.G.G.; Ramírez, M.C.; Barro, F.; Martin, A.; Martín, A.C.C. Molecular and cytological characterization of an extra acrocentric chromosome that restores male fertility of wheat in the msH1 CMS system. Theor. Appl. Genet. 2010, 121, 1093-1101. [CrossRef]

37. Rodríguez-Suárez, C.; Bagnaresi, P.; Cattivelli, L.; Pistón, F.; Castillo, A.; Martín, A.C.; Atienza, S.G.; Ramírez, C.; Martín, A.C. Transcriptomics, chromosome engineering and mapping identify a restorer-of-fertility region in the CMS wheat system msH1. Theor. Appl. Genet. 2020, 133, 283-295. [CrossRef] 
38. Martín, A.C.; Castillo, A.; Atienza, S.G.; Rodríguez-Suárez, C. A cytoplasmic male sterility (CMS) system in durum wheat. Mol. Breed. 2018, 38. [CrossRef]

39. Rodríguez-Suárez, C.; Atienza, S.G.G. Hordeum chilense genome, a useful tool to investigate the endosperm yellow pigment content in the Triticeae. BMC Plant Biol. 2012, 12, 200. [CrossRef] [PubMed]

40. Rodríguez-Suárez, C.; Atienza, S.G. Polyphenol oxidase genes in Hordeum chilense and implications in tritordeum breeding. Mol. Breed. 2014, 34, 1867-1877. [CrossRef]

41. Rodríguez-Suárez, C.; Mellado-Ortega, E.; Hornero-Méndez, D.; Atienza, S.G. Increase in transcript accumulation of Psy1 and $e-L c y$ genes in grain development is associated with differences in seed carotenoid content between durum wheat and tritordeum. Plant Mol. Biol. 2014, 84, 659-673. [CrossRef]

42. Forster, B.P.; Phillips, M.S.; Miller, T.E.; Baird, E.; Powell, W. Chromosome location of genes controlling tolerance to salt (NaCl) and vigour in Hordeum vulgare and H. chilense. Heredity 1990, 65, 99-107. [CrossRef]

43. Rey, M.-D.; Calderon, M.C.; Prieto, P. The use of the ph1b mutant to induce recombination between the chromosomes of wheat and barley. Front. Plant Sci. 2015, 6. [CrossRef]

44. Alvarez, J.B.; Martin, L.M.; Martin, A. Chromosomal localization of genes for carotenoid pigments using addition lines of Hordeum chilense in wheat. Plant Breed. 1998, 117, 287-289. [CrossRef]

45. Mattera, M.G.; Cabrera, A.; Hornero-Méndez, D.; Atienza, S.G. Lutein esterification in wheat endosperm is controlled by the homoeologous group 7, and is increased by the simultaneous presence of chromosomes 7D and 7H ${ }^{\text {ch }}$ from Hordeum chilense. Crop Pasture Sci. 2015, 66, 912-921. [CrossRef]

46. Requena-Ramírez, M.D.; Atienza, S.G.; Hornero-Méndez, D.; Rodríguez-Suárez, C. Mediation of a GDSL Esterase/Lipase in Carotenoid Esterification in Tritordeum Suggests a Common Mechanism of Carotenoid Esterification in Triticeae Species. Front. Plant Sci. 2020, 11, 2032. [CrossRef] [PubMed]

47. Alvarez, J.B.; Castellano, L.; Recio, R.; Cabrera, A. Wx Gene in Hordeum chilense: Chromosomal Location and Characterisation of the Allelic Variation in the Two Main Ecotypes of the Species. Agronomy 2019, 9, 261. [CrossRef]

48. Hernandez, P. Comparison among available marker systems for cereal introgression breeding: A practical perspective. Euphytica 2005, 146, 95-100. [CrossRef]

49. Hernández, P.; Dorado, G.; Prieto, P.; Giménez, M.J.; Ramírez, M.C.; Laurie, D.A.; Snape, J.W.; Martín, A. A core genetic map of Hordeum chilense and comparisons with maps of barley (Hordeum vulgare) and wheat (Triticum aestivum). Theor. Appl. Genet. 2001, 102, 1259-1264. [CrossRef]

50. Vaz Patto, M.C.; Rubiales, D.; Martín, A.; Hernández, P.; Lindhout, P.; Niks, R.E.; Stam, P. QTL mapping provides evidence for lack of association of the avoidance of leaf rust in Hordeum chilense with stomata density. Theor. Appl. Genet. 2003, 106, 1283-1292. [CrossRef]

51. Atienza, S.G.; Ramírez, C.M.; Hernández, P.; Martín, A. Chromosomal location of genes for carotenoid pigments in Hordeum chilense. Plant Breed. 2004, 123. [CrossRef]

52. Hagras, A.A.A.; Kishii, M.; Sato, K.; Tanaka, H.; Tsujimoto, H. Extended application of barley EST markers for the analysis of alien chromosomes added to wheat genetic background. Breed. Sci. 2005, 55, 335-341. [CrossRef]

53. Hagras, A.A.-A.; Kishii, M.; Tanaka, H.; Sato, K.; Tsujimoto, H. Genomic differentiation of Hordeum chilense from H. vulgare as revealed by repetitive and EST sequences. Genes Genet. Syst. 2005, 80, 147-159. [CrossRef] [PubMed]

54. Ozkan, H.; Levy, A.A.; Feldman, M. Allopolyploidy-Induced Rapid Genome Evolution in the Wheat (Aegilops-Triticum) Group. Plant Cell 2001, 13, 1735-1747. [CrossRef]

55. Cabo, S.; Ferreira, L.; Carvalho, A.; Martins-Lopes, P.; Martín, A.; Lima-Brito, J.E. Potential of Start Codon Targeted (SCoT) markers for DNA fingerprinting of newly synthesized tritordeums and their respective parents. J. Appl. Genet. 2014, 55, 307-312. [CrossRef]

56. Cabo, S.; Carvalho, A.; Rocha, L.; Martin, A.; Lima-Brito, J. IRAP, REMAP and ISSR Fingerprinting in Newly Formed Hexaploid Tritordeum (×Tritordeum Ascherson et Graebner) and Respective Parental Species. Plant Mol. Biol. Rep. 2014, 32, 761-770. [CrossRef]

57. Rodríguez-Suárez, C.; Giménez, M.J.; Gutiérrez, N.; Ávila, C.M.; Machado, A.; Huttner, E.; Ramírez, M.C.; Martín, A.C.; Castillo, A.; Kilian, A.; et al. Development of wild barley (Hordeum chilense)-derived DArT markers and their use into genetic and physical mapping. Theor. Appl. Genet. 2012, 124, 713-722. [CrossRef]

58. Castillo, A.; Ramírez, M.C.; Martín, A.C.; Kilian, A.; Martín, A.C.; Atienza, S.G. High-throughput genotyping of wheat-barley amphiploids utilising diversity array technology (DArT). BMC Plant Biol. 2013, 13. [CrossRef]

59. Nasuda, S.; Kikkawa, Y.; Ashida, T.; Rafiqul Islam, A.K.M.; Sato, K.; Endo, T.R. Chromosomal assignment and deletion mapping of barley EST markers. Genes Genet. Syst. 2005, 80, 357-366. [CrossRef]

60. Quraishi, U.M.; Abrouk, M.; Bolot, S.; Pont, C.; Throude, M.; Guilhot, N.; Confolent, C.; Bortolini, F.; Praud, S.; Murigneux, A.; et al. Genomics in cereals: From genome-wide conserved orthologous set (COS) sequences to candidate genes for trait dissection. Funct. Integr. Genomics 2009, 9, 473-484. [CrossRef] [PubMed]

61. The International Barley Genome Sequencing Consortium. A physical, genetic and functional sequence assembly of the barley genome. Nature 2012, 491, 711-716. [CrossRef] [PubMed] 
62. Ávila, C.M.; Mattera, M.G.; Rodríguez-Suárez, C.; Palomino, C.; Ramírez, M.C.; Martin, A.; Kilian, A.; Hornero-Méndez, D.; Atienza, S.G. Diversification of seed carotenoid content and profile in wild barley (Hordeum chilense Roem. et Schultz.) and Hordeum vulgare L.-H. chilense synteny as revealed by DArTSeq markers. Euphytica 2019, 215, 45. [CrossRef]

63. Elouafi, I.; Nachit, M.M.; Martin, L.M. Identification of a microsatellite on chromosome 7B showing a strong linkage with yellow pigment in durum wheat (Triticum turgidum L. var. durum). Hereditas 2001, 135, 255-261. [CrossRef]

64. Alvarez, J.B.; Ballesteros, J.; Sillero, J.A.; Martin, L.M. Tritordeum: A new crop of potential importance in the food industry. Hereditas 1992, 116, 193-197. [CrossRef]

65. Bhave, M.; Morris, C.F. Molecular genetics of puroindolines and related genes: Allelic diversity in wheat and other grasses. Plant Mol. Biol. 2008, 66, 205-219. [CrossRef]

66. Guzmán, C.; Alvarez, J.B. Molecular characterization of two novel alleles of Hordoindoline genes in Hordeum chilense Roem. et Schult. Genet. Resour. Crop Evol. 2014, 61, 307-312. [CrossRef]

67. Yanaka, M.; Takata, K.; Terasawa, Y.; Ikeda, T.M. Chromosome 5H of Hordeum species involved in reduction in grain hardness in wheat genetic background. Theor. Appl. Genet. 2011, 123, 1013-1018. [CrossRef]

68. Payne, P.I.; Nightingale, M.A.; Krattiger, A.F.; Holt, L.M. The relationship between HMW glutenin subunit composition and the bread-making quality of British-grown wheat varieties. J. Sci. Food Agric. 1987, 40, 51-65. [CrossRef]

69. Barro, F.; Barceló, P.; Lazzeri, P.A.; Shewry, P.R.; Martín, A.; Ballesteros, J. Functional properties and agronomic performance of transgenic tritordeum expressing high molecular weight glutenin subunit genes 1Ax1 and 1Dx5. J. Cereal Sci. 2003, 37, 65-70. [CrossRef]

70. Barro, F.; Barcelo, P.; Lazzeri, P.A.; Shewry, P.R.; Ballesteros, J.; Martin, A. Functional properties of flours from field grown transgenic wheat lines expressing the HMW glutenin subunit 1Ax1 and 1Dx5 genes. Mol. Breed. 2003, 12, 223-229. [CrossRef]

71. Ballesteros, J.; Alvarez, J.B.; Gimenez, M.J.; Ramirez, M.C.; Cabrera, A.; Martin, A. Introgression of 1Dx5+1Dy10 into Tritordeum. Theor. Appl. Genet. 2003, 106, 644-648. [CrossRef]

72. Ballesteros, J.; Ramírez, M.C.; Martínez, C.; Barro, F.; Martín, A. Bread-making quality in hexaploid tritordeum with substitutions involving chromosome 1D. Plant Breed. 2003, 122, 89-91. [CrossRef]

73. Alvarez, J.B.; Martín, A.; Martín, L.M. Variation in the high-molecular-weight glutenin subunits coded at the Glu-Hch1 locus in Hordeum chilense. Theor. Appl. Genet. 2001, 102, 134-137. [CrossRef]

74. Atienza, S.G.; Gimenez, M.J.; Martin, A.; Martin, L.M. Variability in monomeric prolamins in Hordeum chilense. Theor. Appl. Genet. 2000, 101, 970-976. [CrossRef]

75. Atienza, S.G.; Alvarez, J.B.; Villegas, A.M.; Gimenez, M.J.; Ramirez, M.C.; Martin, A.; Martin, L.M. Variation for the low-molecularweight glutenin subunits in a collection of Hordeum chilense. Euphytica 2002, 128, 269-277. [CrossRef]

76. Alvarez, J.B.; Broccoli, A.; Martín, L.M. Variability and Genetic Diversity for Gliadins in Natural Populations of Hordeum chilense Roem. et Schult. Genet. Resour. Crop Evol. 2006, 53, 1419-1425. [CrossRef]

77. Alvarez, J.B.; Moral, A.; Martín, L.M.; Martín, A. Linkage relationships between prolamin genes located on chromosome $1 \mathrm{H}^{\mathrm{ch}}$ in Hordeum chilense. Theor. Appl. Genet. 2004, 108, 891-895. [CrossRef]

78. Caballero, L.; Alvarez, J.B.; Martin, L.M. Analysis of D-prolamins synthesized by the Hordeum chilense genome and their effects on gluten strength in hexaploid tritordeum. Plant Breed. 2001, 120, 185-187. [CrossRef]

79. Vaquero, L.; Comino, I.; Vivas, S.; Rodríguez-Martín, L.; Giménez, M.J.; Pastor, J.; Sousa, C.; Barro, F. Tritordeum: A novel cereal for food processing with good acceptability and significant reduction in gluten immunogenic peptides in comparison with wheat. J. Sci. Food Agric. 2018, 98, 2201-2209. [CrossRef]

80. Sánchez-León, S.; Haro, C.; Villatoro, M.; Vaquero, L.; Comino, I.; González-Amigo, A.B.; Vivas, S.; Pastor, J.; Sousa, C.; Landa, B.B.; et al. Tritordeum breads are well tolerated with preference over gluten-free breads in non-celiac wheat-sensitive patients and its consumption induce changes in gut bacteria. J. Sci. Food Agric. 2020, jsfa.10982. [CrossRef]

81. Idehen, E.; Tang, Y.; Sang, S. Bioactive phytochemicals in barley. J. Food Drug Anal. 2017, 25, 148-161. [CrossRef] [PubMed]

82. Navas-Lopez, J.F.; Ostos-Garrido, F.J.; Castillo, A.; Martín, A.; Gimenez, M.J.; Pistón, F. Phenolic content variability and its chromosome location in tritordeum. Front. Plant Sci. 2014, 5. [CrossRef]

83. Eliášová, M.; Paznocht, L. Total phenolic content and antioxidant activity of tritordeum wheat and barley. Agron. Res. 2017, 15, 1287-1294.

84. Lachman, J.; Hejtmánková, A.; Orsák, M.; Popov, M.; Martinek, P. Tocotrienols and tocopherols in colored-grain wheat, tritordeum and barley. Food Chem. 2018, 240, 725-735. [CrossRef]

85. Rakha, A.; Saulnier, L.; Åman, P.; Andersson, R. Enzymatic fingerprinting of arabinoxylan and $\beta$-glucan in triticale, barley and tritordeum grains. Carbohydr. Polym. 2012, 90, 1226-1234. [CrossRef]

86. Phuong, L.E.; Lachman, J.; Kotíková, Z.; Orsák, M.; Michlová, T.; Martinek, P. Selenium in colour-grained winter wheat and spring tritordeum. Plant Soil Environ. 2017, 63, 315-321. [CrossRef]

87. Tufarelli, V.; Cazzato, E.; Ceci, E.; Laudadio, V. Selenium-Fertilized Tritordeum ( $\times$ Tritordeum Ascherson et Graebner) as Dietary Selenium Supplement in Laying Hens: Effects on Egg Quality. Biol. Trace Elem. Res. 2016, 173, 219-224. [CrossRef] [PubMed]

88. Gómez, M.; Manchón, L.; Oliete, B.; Ruiz, E.; Caballero, P.A. Adequacy of wholegrain non-wheat flours for layer cake elaboration. LWT Food Sci. Technol. 2010, 43, 507-513. [CrossRef]

89. Zdaniewicz, M.; Pater, A.; Hrabia, O.; Duliński, R.; Cioch-Skoneczny, M. Tritordeum malt: An innovative raw material for beer production. J. Cereal Sci. 2020, 96, 103095. [CrossRef] 
90. Nocente, F.; Natale, C.; Galassi, E.; Taddei, F.; Gazza, L. Using Einkorn and Tritordeum Brewers' Spent Grain to Increase the Nutritional Potential of Durum Wheat Pasta. Foods 2021, 10, 502. [CrossRef]

91. Ballesteros, J.; Ramirez, M.C.; Martinez, C.; Atienza, S.G.; Martin, A. Registration of HT621, a high carotenoid content tritordeum germplasm line. Crop Sci. 2005, 45, 2662-2663. [CrossRef]

92. Atienza, S.G.; Avila, C.M.; Ramírez, M.C.; Martín, A. Application of near infrared reflectance spectroscopy to the determination of carotenoid content in tritordeum for breeding purposes. Aust. J. Agric. Res. 2005, 56, 85-89. [CrossRef]

93. Atienza, S.G.; Avila, C.M.; Martín, A. The development of a PCR-based marker for PSY1 from Hordeum chilense, a candidate gene for carotenoid content accumulation in tritordeum seeds. Aust. J. Agric. Res. 2007, 58, 767-773. [CrossRef]

94. Rodríguez-Suárez, C.; Atienza, S.G.; Pistón, F. Allelic variation, alternative splicing and expression analysis of Psy1 gene in Hordeum chilenseRoem. et Schult. PLoS ONE 2011, 6. [CrossRef]

95. Atienza, S.G.; Ballesteros, J.; Martin, A.; Hornero-Mendez, D. Genetic variability of carotenoid concentration and degree of esterification among tritordeum ( $\times$ Tritordeum Ascherson et Graebner) and durum wheat accessions. J. Agric. Food Chem. 2007, 55, 4244-4251. [CrossRef]

96. Berry, H.M.; Rickett, D.V.; Baxter, C.J.; Enfissi, E.M.A.; Fraser, P.D. Carotenoid biosynthesis and sequestration in red chilli pepper fruit and its impact on colour intensity traits. J. Exp. Bot. 2019, 70, 2637-2650. [CrossRef] [PubMed]

97. Mattera, M.G.; Hornero-Méndez, D.; Atienza, S.G. Carotenoid content in tritordeum is not primarily associated with esterification during grain development. Food Chem. 2020, 310. [CrossRef]

98. Ahmad, F.T.; Asenstorfer, R.E.; Soriano, I.R.; Mares, D.J. Effect of temperature on lutein esterification and lutein stability in wheat grain. J. Cereal Sci. 2013, 58, 408-413. [CrossRef]

99. Subagio, A.; Wakaki, H.; Morita, N. Stability of lutein and its myristate esters. Biosci. Biotechnol. Biochem. 1999, 63, 1784-1786. [CrossRef]

100. Mellado-Ortega, E.; Atienza, S.G.; Hornero-Méndez, D. Carotenoid evolution during postharvest storage of durum wheat (Triticum turgidum conv. durum) and tritordeum (×Tritordeum Ascherson et Graebner) grains. J. Cereal Sci. 2015, 62, 134-142. [CrossRef]

101. Mellado-Ortega, E.; Hornero-Méndez, D. Carotenoid evolution during short-storage period of durum wheat (Triticum turgidum conv. durum) and tritordeum ( $\times$ Tritordeum Ascherson et Graebner) whole-grain flours. Food Chem. 2016, 192, 714-723. [CrossRef] [PubMed]

102. Mellado-Ortega, E.; Hornero-Méndez, D. Effect of long-term storage on the free and esterified carotenoids in durum wheat (Triticum turgidum conv. durum) and tritordeum (×Tritordeum Ascherson et Graebner) grains. Food Res. Int. 2017, 99, 877-890. [CrossRef]

103. Mellado-Ortega, E.; Hornero-Mendez, D. Isolation and identification of lutein esters, including their regioisomers, in tritordeum $(\times$ Tritordeum Ascherson et Graebner) grains: Evidence for a preferential xanthophyll acyltransferase activity. Food Chem. 2012, 135, 1344-1352. [CrossRef] [PubMed]

104. Mellado-Ortega, E.; Hornero-Méndez, D. Effect of lutein esterification on the differential distribution of carotenoids in germ and endosperm fractions from tritordeum grains. J. Cereal Sci. 2018, 79, 462-468. [CrossRef]

105. Paznocht, L.; Burešová, B.; Kotíková, Z.; Martinek, P. Carotenoid content of extruded and puffed products made of colored-grain wheats. Food Chem. 2021, 340. [CrossRef] [PubMed]

106. Watkins, J.L.; Li, M.; McQuinn, R.P.; Chan, K.X.; McFarlane, H.E.; Ermakova, M.; Furbank, R.T.; Mares, D.J.; Dong, C.; Chalmers, K.J.; et al. A GDSL Esterase/Lipase Catalyzes the Esterification of Lutein in Bread Wheat. Plant Cell 2019. [CrossRef] [PubMed]

107. Watkins, J.; Pogson, B.; Mather, D. XAT Catalyzes Carotenoid Esterification in Wheat. Available online: https://plantae.org/xatcatalyzes-carotenoid-esterification-in-wheat/ (accessed on 20 May 2021).

108. Mellado-Ortega, E.; Hornero-Méndez, D. Carotenoid profiling of Hordeum chilense grains: The parental proof for the origin of the high carotenoid content and esterification pattern of tritordeum. J. Cereal Sci. 2015, 62, 15-21. [CrossRef]

109. Ávila, C.M.; Palomino, M.C.; Hornero-Méndez, D.; Atienza, S.G. Identification of candidate genes for lutein esterification in common wheat (Triticum aestivum) using physical mapping and genomics tools. Crop Pasture Sci. 2019, 70, 567-574. [CrossRef] 